\title{
ANALYSIS OF ACCOUNTING STUDENT'S UNDERSTANDING OF BASIC ACCOUNTING CONCEPTS
}

\author{
Ladzina Shafira Zahra ${ }^{1}$, Audita Setiawan ${ }^{2}$ \\ ${ }_{1,2}$ Universitas Sangga Buana YPKP Bandung \\ ${ }^{1}$ correspondence: ladzinazahra1708@gmail.com
}

\begin{abstract}
The purpose of this study is to empirically prove the differences in understanding. The formulation of the problem is to empirically prove whether there are differences in the understanding of students from high school with a science major and high school majoring in social studies on the basic concepts of accounting. The basic concept of accounting in this study uses the variables of assets, liabilities, and capital. This research was conducted at a private university in West Java. The data is primary data, and the data collection technique is using a questionnaire. The population and sample in this study were 52 students majoring in accounting for the 2019-2020 class based on certain criteria. The data analysis technique of this research is descriptive statistical analysis, using validity, reliability and Kruskal Wallis difference test with IBM SPSS Statistics version 23 to measure the level of understanding of students from high school majoring in science and high school majoring in social studies on the basic concepts of accounting.

The results of this study stated that only the variable Capital (Equity) had a significant difference in understanding between students from high school majoring in science and high school majoring in social studies. Where the other two variables, namely Assets and Liabilities, show that there is no significant difference in understanding between students from Senior High School from the Science Department and Senior High School from the Social Sciences Department.
\end{abstract}

Keywords: Understanding Assets, Liabilities, and Capital

\section{INTRODUCTION}

Higher education is a place to develop the potential for the development of science broadly so that the development of knowledge does not end in high school alone. The development of science will improve the quality of human resources, where the higher the quality of human resources, the education in a nation will develop. Currently, the government's efforts in relation to education are developing curriculum, providing scholarships to outstanding students and improving the quality of the workforce as part of efforts to develop education.

In this case, universities are organized to be able to prepare students to become members of the community who have not only academic abilities but also professional abilities di that knowledge and science as well as arts and technology can be applied, develop, or even created.

Thus, universities that provide higher education can provide a very large role in creating Indonesian human resources that have the best quality.

Studying in higher education is a journey that is not always easy because students will face challenges and obstacles. Choosing a major is one of the challenges so that the choice can be in accordance with oneself and does not become a choice that has negative consequences in the future. 
One of the developmental tasks experienced by university students in the first year is selfknowledge about their interests, skills, values and commitment to the chosen career path or department [1].

Based on the Big Indonesian Dictionary, the department is part of a faculty or high school that develops a field of study or study of science in particular and is divided into various fields. One of the fields of science that has become a hobby and has enthusiasts in the community in pursuing higher education is economics. This is because economics is a field of science which in practice drives the activities of companies and the state. Fields in the economy that have a crucial role for economic growth and fields that contribute greatly to companies include the field of accounting.

The key to being skilled in mastering accounting is first to understand the basic concepts of accounting. The basic concepts of accounting that have been understood will facilitate the implementation of activities related to accounting science. By choosing the field of accounting as a major choice, both at the secondary and higher education levels

Education in the field of accounting aims to produce graduates who have good ethics and morals. Various things are consistently carried out to introduce the professional values of professional accountants to students. To develop professional accounting education will require feedback that answer whether accounting education implemented in Indonesia qualified in the formation of a positive value accounting students. Some students have the perception that accounting is a difficult field of science, this condition, among other things, occurs because the previous education major is different from accounting.

The fact that occurs shows that students who are studying in higher education come from heterogeneous or different ability backgrounds. For example, students from the accounting study program come from high school graduates from either Science or Social Sciences, Vocational High Schools in business management and others, Madrasah Aliyah level also come from different educational

backgrounds. Difsferent educational backgrounds cause different content in the curriculum, which is related to the provision of accounting science subjects. For schools that have accounting subjects also do not always have the same accounting material content, so the experience and learning materials for accounting will also be different. Research conducted with the title "Analysis of Student Understanding of Introductory Accounting Courses Based on Educational Background and Gender (Empirical Studies of Accounting Study Program Students at the Islamic University of Kuantan Singingi)" shows that there is no difference in understanding of introductory accounting courses between students with different backgrounds between the Sciences and Social Science midwives, but there are differences regarding the understanding of 
introductory accounting courses for different genders of students. [2]

\section{LITERATURE REVIEW}

Identification, recording and communication of an economic event is a fundamental activity of an organization to interested parties. [3] The company identifies the existence of economic events that are in accordance with business activities and these events are recorded so that a record of financial activities is available. Recording is carried out systematically, chronologically of each event, in currency units. In the end, this set of information will then be submitted to the manager or parties who have an interest in an accounting report or financial report.

\section{Accounting Understanding}

Comprehension is the ability to understand or understand from someone then know and remember it [4]. So, it can be said that understanding is knowing something and the ability to see things from various aspects. A person who understands will be able to provide an explanation and explain a more detailed description using his own words and sentences.

There are three indicators in the category of understanding, namely: [5]

1. The lowest level is understanding translation, this level begins with translating in the true sense, begins with interpreting and then applies rules or principles.
2. The second level is interpretive understanding, with activities connecting the previous parts with the next known or connecting some parts of the graph with events, distinguishing the main and the non-essential.

3. The third level of understanding or the highest level is extrapolated understanding. With extrapolation, it is expected to be able to see the meaning behind what is written, to be able to make predictions about the consequences that will arise or to be able to expand the perception of the meaning of dimensions, time, cases or problems.

Thus, showing that understanding is a skill to understand things in their entirety thoroughly from all aspects so that they can be redescribed and explained again using different sentences or languages. So understanding is not limited to knowing and understanding but must be able to remember and be able to convey the meaning and meaning of the material that has been studied so that there is no confusion in making interpretations.

Understanding is crucial in exploring something because it relates to the level of intelligence or understanding. The level of intelligence possessed determines a person's abilities. Success in completing work is determined by the level of intelligence possessed by each.

The factors that influence understanding are internal and external factors: 
These factors come from within students, including psychological factors related to students' souls and desires which include motives, intelligence, attention, and interests as well as talents of students.

\section{b. External Factors}

External factors are factors that arise from outside the students themselves, namely factors that support learning outcomes in students including family factors, teaching methods, teachers, and facilities, as well as the environment.

\section{Basic Accounting Concepts}

Organizations or companies have resources known as assets. Then the rights or claims on assets are divided into 2 (two), namely the rights of creditors and the rights of owners. Creditor rights are the obligations of the company, while the owner's rights are equity. The relationship between the two things is illustrated in an equation called the basic accounting equation. [6]

\section{Accounting Knowledge}

Accounting knowledge is a set of knowledge about information systems that provide financial reports for interested parties about economic activities and company conditions. Accounting knowledge can be defined as a set of knowledge that compiles about how to record, classify, and summarize financial transactions and events in an efficient manner and in the form of units of money, interpreting the results of the process in the form of quantitative information used for economic decision making as a basis for choosing various alternatives. [7]

Accounting is an art to collect, identify, classify, record transactions and events related to finance, to produce financial information or a financial report that can be used by interested parties. [8]

It can be concluded that the definition of accounting is a process of collecting, identifying, classifying, and recording transactions and events related to finance. The process produces financial information that is useful for users of the report (users) for decision making.

Differences in understanding of the basic concepts of accounting for Assets for students who have different backgrounds from High School majoring in sciences and social sciences.

There were no differences in understanding the basic concepts of accounting asset among students who come from high school science majors and the social sciences, it is because of the understanding gained in secondary education different accounting education that will be obtained in college so the students will get lessons more specifically. If you look at the difference in terms of understanding the basic concepts of accounting regarding assets taught at school, it only focuses on basic things such as types of assets and simple journals, this is because accounting is a subject that is incorporated in economics subjects, so it is not focused specialized in accounting. 
$\mathrm{H} 1$ : There is no significant difference in the understanding of accounting students with a high school background majoring in science and social studies, regarding assets.

Differences in understanding of the basic concepts of accounting for Liabilities of students who come from high school backgrounds majoring in science and social sciences.

There were no differences regarding the understanding of the basic concepts of accounting liabilities among students who come from a background of senior high school majoring in science and high school majoring in social studies, it is because the understanding of education obtained while in secondary education differs from accounting education that will be obtained dibangku college students will get specific learning. If you look at the difference in terms of understanding the basic concepts of accounting regarding Liabilities taught at school, it only focuses on basic things such as understanding obligations and types of obligations, this is because the accounting subjects themselves are combined into one with economics subjects so that not focused on accounting only.

$\mathrm{H} 2$ : There is no significant difference in the understanding of accounting students with a high school background majoring in science, high school majoring in social studies, about liabilities.

Differences in understanding of the basic concepts of Equity accounting students from high school majoring in science and high school majoring in social studies. The highest level of understanding on the basic concepts of Equity accounting is owned by students from high school majoring in science, and high school majoring in social sciences. This is because students from school background majoring in science in the study had levels of intelligence are better than students coming from the direction of senior high school social studies so that even when the school received very little knowledge on the basic concepts of accounting, especially Equity but at when studying, students in the science major can carry out learning very well related to the basic concepts of accounting, especially Equity.

H3: There is a significant difference in the understanding of accounting students with a high school background majoring in science, high school majoring in social studies, about equity. 


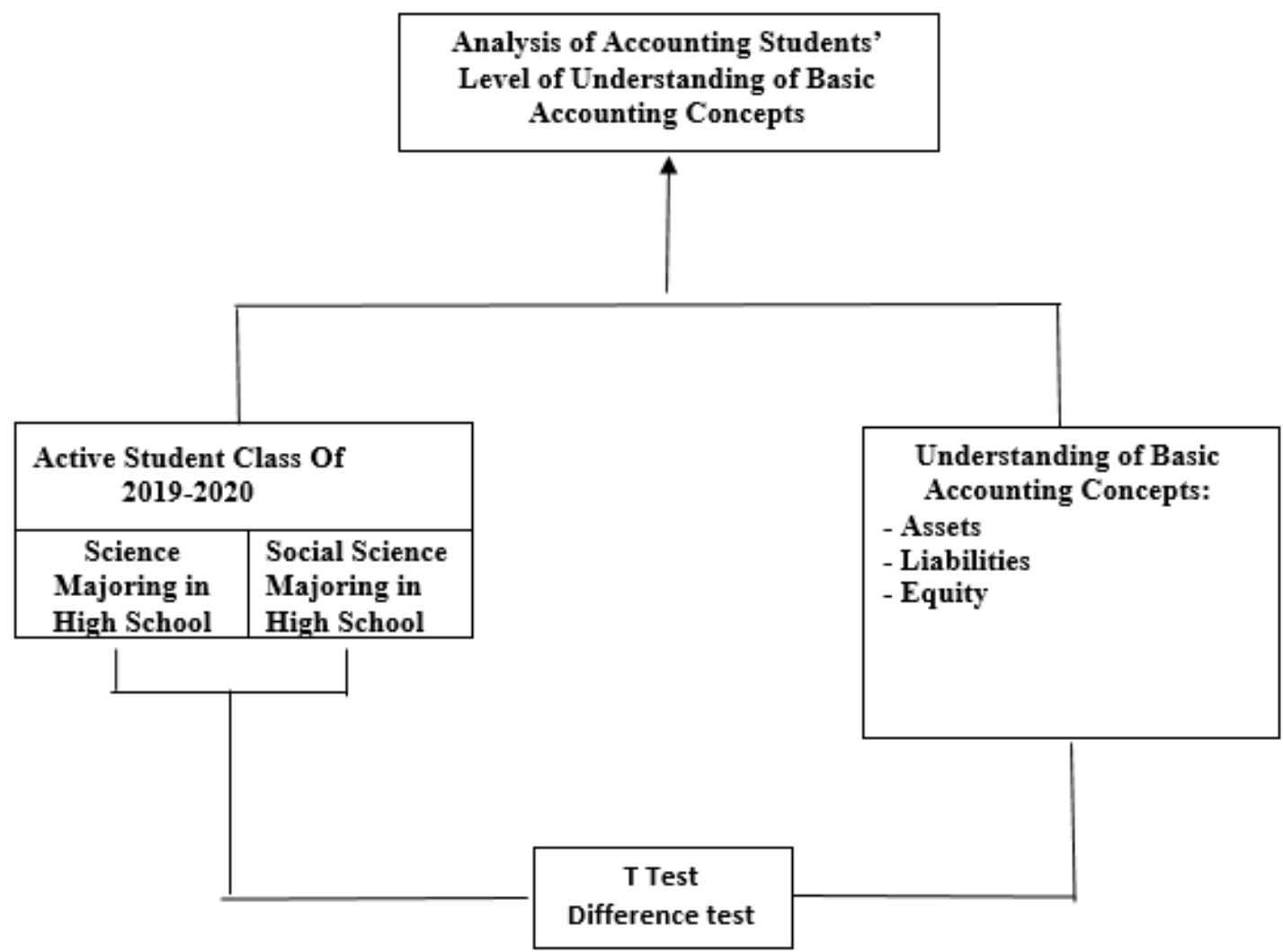

Figure 1 : Research Paradigm

\section{RESEARCH METHODS}

\section{Research design}

This research is associative research with a quantitative approach. Associative research is research that is asking the relationship between two or more variables. [9] 2018:63). Quantitative research is research based on the philosophy of positivism, used to examine certain populations or samples, collect data using research instruments, analyze quantitative/statistical data, with the aim of testing hypotheses. [10]

\section{Sampling Population And Sampling Techniques}

Population is defined as a generalization area consisting of objects/subjects that have certain qualities and characteristics that have been determined by researchers to be studied and then drawn conclusions. [10]

The population in this study were active students of the Accounting Study Program one of Private Universities in West Java as many as $\mathbf{5 2}$ students.

In this study, not all populations were used as samples in the study. The technique used in this research is nonprobability sampling technique with purposive sampling technique. Therefore, the authors chose a purposive sampling technique which stipulates certain considerations or criteria that must be met by the samples used in this study. 
In this study, the sample is active students of the Accounting Study Program. The criteria used as research samples are:

1. An active student of the 2019 bachelor's degree Accounting Study Program, one of the private universities in West Java.

2. An active student of the 2020 bachelor's degree Accounting Study
Program, one of the private universities in West Java.

\section{RESULTS AND DISCUSSION}

In this study, a descriptive analysis will be carried out based on the origin of the school and the data on understanding the basic concepts of accounting (assets/assets, liabilities/liabilities, capital/equity).

Table 1 : Descriptive Analysis

\begin{tabular}{|l|r|r|r|r|r|}
\hline & N & Minimum & Maximum & mean & Std. Deviation \\
\hline Assets & 52 & 18 & 29 & 24.38 & 2,918 \\
Liabilities & 52 & 23 & 35 & 29.62 & 2,545 \\
Equity & 52 & 18 & 25 & 21.27 & 1.497 \\
Valid N & 52 & & & & \\
(listwise) & & & & & \\
\hline
\end{tabular}

Source: Results of data processing with SPSS 23

Based on the results of descriptive statistics in Table 1 indicates that, on an asset variable has a minimum value of 18 , the maximum is 29 , standard deviation of 2.918 and an average value or a mean of 24.38. So, if respondents had an average value of more than 24.38 of the respondents have knowledge of Assets that meet the criteria or the respondents' answers can be used as research material.

Variable Liabilities has a minimum value of 23 , the maximum is 35 , standard deviation of 2.545 and an average value or a mean of
29.62. So, if respondents had an average value of more than 29.62 of the respondents have knowledge of Liabilities that meet the criteria or the respondents' answers can be used as research material.

The Equity variable has a minimum value of 18 , a maximum value of 25 , a standard deviation of 1.497 and an average value or mean of 21.27. So, if the respondent's answer has an average value of more than 21.27, the respondent has knowledge of Equity that meets the criteria or the respondent's answer can be used as research material. 


\section{Validity test}

Table 2 : Validity test

\begin{tabular}{|c|c|c|c|c|}
\hline \multirow[b]{2}{*}{ Variable } & \multirow[b]{2}{*}{ Question } & \multicolumn{2}{|c|}{ Validity } & \multirow[b]{2}{*}{ Decision } \\
\hline & & $\begin{array}{c}\text { Correlation } \\
\text { r count }\end{array}$ & $r$ table & \\
\hline \multirow[t]{7}{*}{ Assets (Assets) } & P1 & 0.579 & \multirow{7}{*}{0.268} & Valid \\
\hline & P2 & 0.636 & & Valid \\
\hline & P3 & 0.586 & & Valid \\
\hline & P4 & 0.643 & & Valid \\
\hline & P5 & 0.570 & & Valid \\
\hline & P6 & 0.523 & & Valid \\
\hline & P7 & 0.543 & & Valid \\
\hline \multirow[t]{8}{*}{ Liabilities } & P1 & 0.490 & \multirow{8}{*}{0.268} & Valid \\
\hline & P2 & 0.497 & & Valid \\
\hline & P3 & 0.468 & & Valid \\
\hline & P4 & 0.533 & & Valid \\
\hline & P5 & 0.566 & & Valid \\
\hline & P6 & 0.704 & & Valid \\
\hline & P7 & 0.536 & & Valid \\
\hline & P8 & 0.442 & & Valid \\
\hline \multirow[t]{7}{*}{ Capital (Equity) } & P1 & 0.374 & \multirow{7}{*}{0.268} & Valid \\
\hline & P2 & 0.511 & & Valid \\
\hline & P3 & 0.555 & & Valid \\
\hline & $\mathrm{P} 4$ & 0.290 & & Valid \\
\hline & P5 & 0.285 & & Valid \\
\hline & P6 & 0.295 & & Valid \\
\hline & P7 & 0.456 & & Valid \\
\hline
\end{tabular}

Source: Results of data processing with SPSS 23

From the results of data processing on the Assets variable using the SPSS program, the results of the validity test of the 7 question items are valid because they show the lowest correlation value of 0.523 , namely at $\mathrm{P} 6$, thus $r$ count $>r$ table $(0.268)$. So, it can be concluded that the 7 question items have been said to be valid and feasible to be used as questionnaire questions and measuring tools for the research conducted. The contents of the conclusion are an overview of the results of the discussion. Conclusions are drawn up in the absence of any cited theory. From the results of data processing on the Liabilities variable using the SPSS program, the results of the validity test of the 8 question items are valid. Because it shows the lowest correlation value of 0.442 , namely at $\mathrm{P} 8$, thus $r$ count $>r$ table $(0.268)$. So, it can be concluded that the 8 question items have been said to be valid and worthy of being used as questionnaire questions and measuring tools for the research conducted. 
From the results of data processing on the Equity variable using the SPSS program, the results of the validity test of the 7 question items are valid. Because it shows the lowest correlation value of 0.285 , namely at $\mathrm{P} 6$, thus $r$ count $>r$ table $(0.268)$. So, it can be concluded that the 7 question items have been said to be valid and worthy of being used as questionnaire questions and measuring tools for the research conducted.

\section{Reliability Test}

Table 2 : Reliability Test

\begin{tabular}{|c|c|c|c|}
\hline Variable & \multicolumn{2}{|c|}{ Reliability } & Decision \\
\cline { 2 - 3 } & $\begin{array}{c}\text { Cronbach's } \\
\text { Alpha }\end{array}$ & $\begin{array}{c}\text { Standard } \\
\text { Cronbach's } \\
\text { Alpha }\end{array}$ & \\
\hline Assets & 0.676 & 0.60 & Reliable \\
\hline Liabilities & 0.631 & 0.60 & Reliable \\
\hline Equity & 0.619 & 0.60 & Reliable \\
\hline
\end{tabular}

From the results of data processing on the asset variable using the SPSS program, the results of the reliability test on the asset variable are reliable. Because the value of Cronbach's alpha is 0.676, which means the Cronbach's alpha value is above 0.60. So, the question is used as a measuring tool for variable assets is believed to be consistent if the measurement is made repeatedly.

Results of variable data on liabilities using SPSS shows the results of reliability tests of the Liabilities variables such that reliable. Because the value of Cronbach's alpha is 0.631 , which means the Cronbach's alpha value is above 0.60 . So, the question is used as a measuring tool for variable liabilities is believed to be consistent if the measurement is made repeatedly.

The same is the case with the Assets and Liabilities variable the results of data processing on the Equity variable using the SPSS program show that the results of the reliability test on the Equity variable are also reliable. This is because the value of Cronbach's alpha is 0.619, which means the Cronbach's alpha value is above 0.60 . So that the question that is used as a measuring tool for the Equity variable is believed to be consistent if the measurement is carried out repeatedly.

\section{Kruskal Wallis Test}

Depending on Kruskal Wallis test is used to determine differences in the understanding of Assets, Liabilities and Equity between student background of high school science majors, and high school social studies department. The results of the Kruskal Wallis difference test can be seen in the table below 
Table 4 : Kruskal Wallis Test Results

\begin{tabular}{|c|c|c|c|c|c|c|c|}
\hline & & & & Mean & \multicolumn{2}{|c|}{ Kruskal Wallis Test } & Reception \\
\cline { 5 - 6 } H & Variable & Student & N & rank & Chi Square & Sig (2-tail) & Hypothesis \\
\hline H1 & Assets & S HS & 27 & 27.35 & 0.180 & 0.672 & Rejected \\
& & SS HS & 25 & 25.58 & & & \\
H2 & Liabilities & S HS & 27 & 25.69 & 0.166 & 0.684 & Rejected \\
& & SS HS & 25 & 27.38 & & & \\
H3 & Equity & S HS & 27 & 25.85 & 10,729 & 0.001 & Accepted \\
& & SS HS & 25 & 27.20 & & & \\
\hline
\end{tabular}

Source: Results of data processing with SPSS 23

H1: There is no significant difference in understanding of Assets between students from high school majoring in science, high school majoring in social sciences

From table 4 the Assets variable according to the Chi-square table statistic is $698.32>$ chisquare count of 0.180 , while based on a significant probability of $0.672>0.05$ then $\mathrm{HO}$ is accepted, and $\mathrm{Ha}$ is rejected. These results indicate that there is no difference in understanding between students from high school majoring in Science and high school majoring in Social Sciences.

H2: There is no significant difference in understanding of Liabilities between students from high school majoring in science, and high school majoring in social sciences

From Table 4 shows that the liabilities variable that are statistically Chisquare table at 698.32> chi-square count of 0.166 , while based probability significantly by $0.684>0.05$ then $\mathrm{H} 2$ was rejected because a significant probability value is greater of 0.05 , then $\mathrm{HO}$ is accepted, and $\mathrm{Ha}$ is rejected. These results indicate that there is no difference in understanding between students from high school majoring in science and high school majoring in social studies.

\section{H3: There is a significant difference in} understanding of Equity between students from high school majoring in science, and high school majoring in social sciences. From Table 4 shows that the equity variable that statistically Chi-square table at 698.32> chi-square count of 0,105 , while based on a significant probability of $0.684>$ $0.05, \mathrm{H} 3$ is received, because the value of the more significant probability greater than 0.05 , then $\mathrm{HO}$ is rejected, and Ha accepted. These results indicate that there is a difference in understanding between students from high school majoring in science, and high school majoring in Social Sciences.

\section{CONCLUSION}

Based on the results of research that has been carried out, conclusions can be drawn, including the following:

1. The test results Kruskal Wallis on assets variable seen that in statistics the value of the probability of significance of $0.672>$ 0.05 then $\mathrm{H} 0$ is accepted, and Ha rejected. The decision to reject the 
hypothesis illustrates that from the two research objects there is no significant difference in the understanding of assets based on high school origin.

2. The test results Kruskal Wallis at Liabilities variable looks that are statistisc value the significance probability of $0.684>0.05$ then $\mathrm{H} 0$ is accepted, and Ha rejected. The decision to reject the hypothesis illustrates that from the two research objects there is no significant difference in the understanding of Liabilities, based on High School Origin.

3. The results of the Kruskal Wallis test on the Equity variable show that statistically the significance probability value is $0.001<0.05$, then $\mathrm{H} 0$ is rejected, and $\mathrm{Ha}$ is accepted. The decision to accept the hypothesis illustrates that from the two research objects there are significant differences in the understanding of Equity, based on High School Origin.

\section{REFERENCES}

[1] Abdullah, "Career Decision Making In College Students," Guidena; Journal of Education, Psychology, Guidance and
Counseling, vol. 8, no. 1, pp. 30-39, 2018.

[2] M. I. Shaufani, "STUDENT UNDERSTANDING ANALYSIS OF COURSES INTRODUCTION TO ACCOUNTING BASED ON BACKGROUND," JOM FTK UNIKS, 2019.

[3] D. D. W. T. D. a. W. Kieso, Intermediate Accounting IFRS Edition 2nd Edition, United States: Wiley, 2016.

[4] A. Sudijono, Introduction to Education Statistic, Jakarta: Raja Grafindo Persada, 2015.

[5] N. Sudjana, Assessment of Teaching and Learning Results, Bandung: Rosdikarya, 2016.

[6] A. Indratno, Basic Accounting Principles, Jakarta, 2013.

[7] S. D. H. Sitorus, "The Influence of Educational Background and Knowledge ogf Accounting on The Use of Accounting Information System on Trader in The Helvetia Village Area," $U M S U$, vol. 2, no. 2, pp. 413-416, 2017.

[8] T. Sumarsan, Indonesia Taxation 5th Edition, Jakarta: Index, 2017.

[9] Sugiyono, Combination Research Methods (Mixed Methods), Bandung: CV Alphabet, 2018.

[10] Sugiyono, Quantitative, Qualitative Methods Research. R\&D, Bandung: CV Alphabet, 2019. 